\title{
An update on amniotic bands sequence
}

\author{
Eunice López-Muñoz, M.D. ${ }^{a}$ and Luis E. Becerra-Solano, M.D. ${ }^{a}$
}

\begin{abstract}
Amniotic bands sequence is a congenital disorder characterized by craniofacial, body wall, and limb anomalies that may be associated with fetalplacental fibrous bands. Its prevalence has been reported to range from 0.19 to 8.1 per 10000 births. Different theories have attempted to explain the etiology of amniotic band sequence; however, none has individually been able to support each and every defect observed, so it has been considered to be a multifactorial condition. The (pre- and post-natal) identification of anomalies suggestive of amniotic band sequence is useful for the diagnostic approach and implementation of timely therapeutic interventions favoring the release of the amniotic bands using fetoscopy with recovery of the involved distal limb perfusion, or else the possibility of performing a post-natal surgical repair. It is also helpful to provide genetic counseling. This article offers an update on the epidemiological aspects, etiological theories, risk factors, clinical characteristics, diagnosis (including antenatal diagnosis), genetic counseling, therapeutic approach, and prognosis of amniotic bands sequence.
\end{abstract}

Key words: amniotic bands, constriction ring.

http:/ / dx.doi.org/10.5546/ aap.2018.eng.e409

a. Unidad de Investigación Médica en Medicina Reproductiva, Unidad Médica de Alta Especialidad. Hospital de Ginecoobstetricia $\mathrm{N}^{\circ} 4$ "Luis Castelazo Ayala", Instituto Mexicano del Seguro Social, Ciudad de México.

E-mail address: Eunice López-Muñoz, M.D.:

astridkaryme2001@ yahoo.com.mx

Funding:

None.

Conflict of interest:

None.

Received: 7-6-2017 Accepted: 10-3-2017
To cite: López-Muñoz E, Becerra-Solano LE.An update on amniotic bands sequence. Arch Argent Pediatr 2018;116(3):e409-e420.

\section{INTRODUCTION}

Amniotic bands sequence (ABS) (OMIM \#217100) $)^{1-3}$ is a congenital disorder presenting with fetal anomalies associated with fetalplacental fibrous bands that may cause disruptions, deformations or malformations ${ }^{4}$ without a consistent anatomical pattern. ${ }^{5,6}$ Anomalies are limited to external structures with or without body wall disruption or internal malformations that vary in severity and location. ${ }^{7-9}$ Some authors consider ABS separately from the limb-body wall complex (LBWC), body wall defects (BWD) or the body wall complex (BWC), ${ }^{10-12}$ whereas others believe these are all part of the same disease. ${ }^{13-16}$

\section{Classification}

Although different classifications have been proposed (Table 1), the European Surveillance of Congenital Anomalies (EUROCAT) suggests using the terms "congenital constriction bands" or "amniotic bands" together with the specific description of each identified congenital anomaly. ${ }^{22,23}$

\section{Epidemiology}

The prevalence of ABS with or without LBWC or BWD is variable and has been reported to range from 0.1924 to 8.125 per 10000 births. Such variability lies in the different definitions, terminology, classification, and study population (Table 2).

The prevalence is higher among fetuses of 9-20 weeks of gestational age (178.5 per 10000 cases) $)^{2}$ and stillbirths (191 per 10000 deaths). ${ }^{31}$ Assuming that approximately $20 \%$ of identified pregnancies are lost before 20 weeks of gestational age and $1 \%$ after 20 weeks, a study estimated that per every 100 ABS cases, approximately 90 underwent a miscarriage, 5 were stillbirths, and 5 were born alive, indicating that the frequency of ABS had been underestimated. ${ }^{31}$

\section{Etiology}

Theory of embryonic (endogenous)

dysplasia and derived theories

Streeter ${ }^{32}$ suggested that amniotic bands appeared early during development and were not the primary cause of defects but a consequence of an imperfect histogenesis that caused necrosis, scarring, constrictions, and fusions, and that the deficiency in one or two cells resulted in a larger anomaly of the final structure. ${ }^{32,33}$ McKenzie $^{34}$ supported this theory and suggested that tissue alterations were an example of an abnormal distribution of cell death areas. ${ }^{33-36}$ 
Hartwig et al. ${ }^{37}$ suggested that limb and lateral body wall anomalies were caused by defects in ectodermal placodes, which resulted in mesodermal deficiency and, therefore, abdominal wall deficiency, that was substituted by the amnion and, in the case of rupture, it allowed the abdominal content to fill the extraembryonic celom. ${ }^{36,37}$ Facial and limb anomalies were attributed to a defect in the craniofacial placodes, whereas internal anomalies were explained by the alteration in lateral abdominal placodes that caused an intermediate mesoderm deficiency. ${ }^{33,37}$

TABLE 1. Classifications proposed for amniotic bands sequence

\begin{tabular}{|c|c|c|}
\hline Reference & Bases for classification & Groups \\
\hline Pagon et al., $1979^{17}$ & $\begin{array}{l}\text { Location and extent of the body wall } \\
\text { defect and associated characteristics }\end{array}$ & $\begin{array}{l}\text { Thoracoschisis and/or abdominoschisis (congenital cleft } \\
\text { of the thoracic and/or abdominal wall with } \\
\text { a visceral protrusion) with major cranial malformation, } \\
\text { facial clefts, and amniotic bands } \\
\text { Midline defects with an absent/ rudimentary right lower } \\
\text { limb, right renal aplasia/ hypoplasia, and genital anomalies } \\
\text { Lateral abdominal wall defects with central nervous } \\
\text { system anomalies, external genitalia, } \\
\text { imperforate anus, and short umbilical cord }\end{array}$ \\
\hline Seeds et al., $1982^{5}$ & $\begin{array}{l}\text { Anatomical region where } \\
\text { the defect is located }\end{array}$ & $\begin{array}{l}\text { In the limbs } \\
\text { In the craniofacial region } \\
\text { In the viscera, including omphalocele and gastroschisis }\end{array}$ \\
\hline Van Allen et al., $1987^{18}$ & Type of limb anomaly & $\begin{array}{l}\text { Secondary to vascular and underlying tissue disruption } \\
\text { Secondary to amniotic bands or adhesions } \\
\text { Secondary to deformations versus hemorrhages }\end{array}$ \\
\hline Moerman et al., $1992^{19}$ & $\begin{array}{l}\text { Presence of constriction bands } \\
\text { and associated defects }\end{array}$ & $\begin{array}{l}\text { Constriction bands } \\
\text { Constriction bands and craniofacial defects } \\
\text { Complex defects, including body wall defects with } \\
\text { thoracic or abdominal organ evisceration } \\
\text { (BWD or BWC) }\end{array}$ \\
\hline Russo et al., $1993^{20}$ & LBWC and associated anomalies & $\begin{array}{l}\text { LBWC with exencephaly/encephalocele, facial clefts and } \\
\text { amniotic bands or adhesion between } \\
\text { the cranial defect and the placenta } \\
\text { LBWC without craniofacial defects but with urogenital } \\
\text { anomalies, anal atresia, lumbosacral meningocele, short } \\
\text { umbilical cord or persistent extraembryonic celom }\end{array}$ \\
\hline $\begin{array}{l}\text { Martínez-Frías, } 1997^{11} \\
\text { y Martínez-Frías, } 2000^{12}\end{array}$ & Presence or absence of BWD & $\begin{array}{l}\text { ABS with limb or craniofacial defect or digital constriction } \\
\text { BWD of any cause (except omphalocele and gastroschisis), } \\
\text { including amniotic bands } \\
\text { Severe clefts of the abdominal wall, short / absent } \\
\text { umbilical cord or a cord that extends into the placenta }\end{array}$ \\
\hline Jamsheer et al., $2009^{10}$ & Presence or absence of BWD & $\begin{array}{l}\text { ABS with BWD } \\
\text { ABS without BWD }\end{array}$ \\
\hline Guzmán et al., $2013^{21}$ & Defect location & $\begin{array}{l}\text { Craniofacial and limb defects } \\
\text { Craniofacial and limb defects with BWD } \\
\text { Limb defects with BWD } \\
\text { Isolated craniofacial or limb defects or } \\
\text { BWD in the presence of amniotic bands }\end{array}$ \\
\hline Lowry et al., $2017^{16}$ & $\begin{array}{l}\text { Presence of amniotic bands } \\
\text { and defect location }\end{array}$ & $\begin{array}{l}\text { Amniotic bands / constriction rings with } \\
\text { or without limb defec } \\
\text { BWD with or without limb defect, with or without } \\
\text { amniotic bands / constriction rings } \\
\text { Amniotic bands/constriction rings with craniofacial defects } \\
\text { Amniotic bands / constriction rings with limb } \\
\text { and craniofacial defects } \\
\text { Amniotic bands / constriction rings, } \\
\text { craniofacial defects and BWD }\end{array}$ \\
\hline
\end{tabular}


The objections to this theory are that the mesoderm and the endoderm are established as the epiblasts migrate internally through the primitive streak and are not induced by the ectoderm, ${ }^{33,38}$ limbs originate from the mesoderm with the secondary formation of the apical ectodermal ridge, and internal organs originate in the internal migration of epiblasts through the primitive streak (mesoderm progenitor cells). ${ }^{33,39}$ Hartwig et al. ${ }^{37}$ also suggested the possibility of familial recurrence, which was considered in other case reports. ${ }^{6,19,28,40-44}$ Kruszka et al. ${ }^{13}$ even reported the case of a patient with clinical characteristics of LBWC for whom a heterozygous de novo and nonsynonymous mutation was identified in the IQCK gene (IQ Motif containing K) (c.667C>G;p.Q223E).

\section{Theory of amnion disruption}

Torpin ${ }^{7}$ proposed the amnion rupture or detachment with temporal loss of the amniotic fluid (initial resorption through the chorion) and partial or total emergence of the fetus towards the extraembryonic celom, forming mesodermal fibrous bands between the outer side of the chorion and the amnion, which may cause developmental alterations (constrictions and / or amputations, as well as secondary facial clefts) when coming into contact with the fetus. ${ }^{7,35}$ Higginbottom et al. ${ }^{1}$ supported

TABLE 2. Prevalence of amniotic bands sequence among different populations

\begin{tabular}{|c|c|c|c|c|}
\hline Reference & Source of information & Study period & Reported rate & Other findings \\
\hline $\begin{array}{l}\text { Garza et al., } \\
1988^{15}\end{array}$ & $\begin{array}{l}\text { Metropolitan Atlanta } \\
\text { Congenital Defects Program, } \\
\text { United States of America }\end{array}$ & 1968-1982 & 1.16 per $10000 \mathrm{LBs}$ & $\begin{array}{c}\text { Ratio 1:1.5 } \\
\text { (female/male). }\end{array}$ \\
\hline $\begin{array}{l}\text { Bower et al., } \\
1993^{26}\end{array}$ & $\begin{array}{c}\text { Western Australia } \\
\text { Birth Defects Registry, Australia } \\
\text { South Australia } \\
\text { Birth Defects Registry, Australia }\end{array}$ & $1986-1989$ & 2.03 per $10000 \mathrm{LBs}$ & $\begin{array}{l}\text { Both males and females } \\
\text { equally affected. }\end{array}$ \\
\hline $\begin{array}{l}\text { Czeizel et al., } \\
1987^{27}\end{array}$ & $\begin{array}{l}\text { Hungarian Congenital } \\
\text { Abnormality Registry, Hungary }\end{array}$ & $1975-1984$ & 1.31 per 10000 LBs & $\begin{array}{c}\text { Both males and females } \\
\text { equally affected. }\end{array}$ \\
\hline $\begin{array}{l}\text { Froster et al., } \\
1993^{24}\end{array}$ & $\begin{array}{l}\text { British Columbia Health } \\
\text { Surveillance Registry, Canada }\end{array}$ & $1952-1984$ & $\begin{array}{l}0.19 \text { per } 10000 \text { LBs (limb defect cases } \\
\text { were excluded, even if they occurred } \\
\text { in the presence of constriction rings) }\end{array}$ & $\begin{array}{l}\text { es reported cases were } \\
\text { ed } \\
\text { s) }\end{array}$ \\
\hline $\begin{array}{l}\text { Martínez-Frías, } \\
1997^{11} \\
\qquad(\mathrm{E} \\
\mathrm{Ma}\end{array}$ & $\begin{array}{l}\text { Spanish Collaborative Study } \\
\text { of Congenital Malformations } \\
\text { Estudio Colaborativo Español de } \\
\text { Calformaciones Congénitas), Spain }\end{array}$ & in $1976-1996$ & $\begin{array}{c}0.59 \text { per } 10000 \text { LBs } \quad \text { b } \\
\text { ar } \\
\text { ar }\end{array}$ & $\begin{array}{c}\text { Higher frequency of amniotic } \\
\text { bands isolated among females } \\
\text { and of other anomalies or BWD } \\
\text { among males. }\end{array}$ \\
\hline $\begin{array}{l}\text { Luehr et al., } \\
2002^{28}\end{array}$ & $\begin{array}{c}\text { Tertiary care referral facility } \\
\text { Australia }\end{array}$ & 1996-2001 & $\begin{array}{l}3.3 \text { per } 10000 \text { LBs and } \\
\text { miscarriages / } \\
\text { abortions }\end{array}$ & $\begin{array}{l}\text { Cases who met LBWC criteria. } \\
1 \text { reported case was considered } \\
\text { familial. The prevalence was } \\
\text { not calculated based on } \\
\text { a population registry. }\end{array}$ \\
\hline $\begin{array}{l}\text { Orioli et al., } \\
2003^{29} \text { Stu } \\
\text { (Estuc } \\
\mathrm{d}\end{array}$ & $\begin{array}{l}\text { Latin-American Collaborative } \\
\text { udy of Congenital Malformations } \\
\text { Idio Colaborativo Latino- America } \\
\text { de Malformaciones Congénitas), } \\
\text { South America }\end{array}$ & $\begin{array}{l}1982-1998 \\
\text { ns } \\
\text { cano }\end{array}$ & $\begin{array}{l}0.97 \text { per } 10000 \mathrm{LBs} \\
\text { and deaths }\end{array}$ & $\begin{array}{l}8 \text { reported cases were } \\
\text { consideredfamilial. }\end{array}$ \\
\hline $\begin{array}{l}\text { Jamsheer et al., } \\
2009^{10}\end{array}$ & $\begin{array}{l}\text { Polish Registry of Congenital } \\
\text { Malformations (PRCM), } \\
\text { Poland }\end{array}$ & 1998-2006 & $\begin{array}{l}0.29 \text { per } 10000 \mathrm{LBs} \\
\text { and deaths }\end{array}$ & $\begin{array}{l}\text { Higher severity and } \\
\text { frequencyof anomalies } \\
\text { among patients with BWD. }\end{array}$ \\
\hline $\begin{array}{l}\text { Koskimies et al., } \\
2015^{30}\end{array}$ & $\begin{array}{c}\text { Finnish population } \\
\text { registries, Finland }\end{array}$ & 1993-2005 & $\begin{array}{l}0.9 \text { per } 10000 \mathrm{LBs} \\
\text { and stillbirths }\end{array}$ & Ratio 1:1.46 (female/male). \\
\hline $\begin{array}{l}\text { Lowry et al., } \\
2017^{16}\end{array}$ & $\begin{array}{l}\text { Alberta Congenital Anomalies } \\
\text { Surveillance System, Canada }\end{array}$ & $1980-2012$ & $\begin{array}{l}1.08 \text { per } 10000 \mathrm{LBs}, \\
\text { stillbirths and abortions } \\
(<20 \text { weeks of gestation })\end{array}$ & $\begin{array}{l}\text { Ratio 1:1.15 (female/male). } \\
\text { Higher severity of limb defects } \\
\text { among patients with BWD. }\end{array}$ \\
\hline Guzmán et al., & Registry of the Mate & 1993-2010 & 5 per 10000 LBs & Ratio 1:1.15 \\
\hline
\end{tabular}

The prevalence is not estimated based on a population registry.

ABS: amniotic band sequence; LBs: live births; BWD: body wall defects; LBWC: limb-body wall complex. 
this theory and proposed that an early damage (before 45 days of gestation) caused craniofacial clefts and severe cranial and brain anomalies frequently but not always with constriction rings and amputations, whereas late damage (after 45 days of gestation) affected the limbs more. They suggested that neural tube defects and facial clefts were caused by band disruption and/or compression, whereas BWD were considered a primary malformation. ${ }^{1,35,45,46}$ Davies et al. ${ }^{47}$ reported an association between fetal amniotic adhesions and multiple malformations, which predominately occurred in the same area and on the same side, thus supporting the theory of amniotic adhesions as the initial factor.

Romero et al. ${ }^{48}$ maintained that ABS was generated by the early rupture of amniotic and chorionic membranes and also proposed that the epithelial-mesenchymal transition was a factor that could contribute to ABS pathogenesis. ${ }^{49-51}$ The objections to the theory of amnion disruption are that there is no evidence of the initial resorption of amniotic fluid through the chorion or of the abrasive nature of the chorion on the fetal skin and the presence of anomalies without evidence of amnion rupture or amniotic bands, so damage should occur very early during gestation to account for some associated anomalies, and the presence of internal malformations (in the kidneys and the heart) cannot be explained by such mechanical phenomenon. $33,35,52-54$

\section{Theory of vascular disruption}

Van Allen et al. ${ }^{18}$ proposed that internal or external events caused vascular accidents or had a negative impact on blood flow to the embryo because they interrupted the morphogenesis or destructed structures, whereas amniotic bands were a form of superficial necrosis. This theory was supported by some experiments in animal models that resulted in anomalies following an amniotic puncture ${ }^{55,56}$ and the demonstration of vascular alterations proximal to the band or the amputation. ${ }^{57}$ The objections to this theory are that humans do not undergo such immediate loss of amniotic fluid following the rupture of the amniotic membrane during early pregnancy, so that such vascular changes are not expected to occur that account for the alterations observed in ABS. ${ }^{37}$ Another objection is that, compared to other cases of ABS, acardiac twins (considered the clearest example of vascular disruption) show a pattern of different anomalies, so the probability of the same causal mechanism is low. ${ }^{58}$

\section{Theory of disorganization}

The mouse mutant disorganization (Ds) gene was initially described by Hummel, ${ }^{59}$ however, this gene has not been identified in humans. ${ }^{60} \mathrm{It}$ has been proposed that limb anomalies in humans may be equivalent to those reported in $\mathrm{Ds}^{61-69}$ although some characteristics observed in ABS are not part of the phenotype described. ${ }^{33,70}$

\section{Hypothesis of primary ectodermal failure} in the early embryonic disc

Hunter et al. ${ }^{33}$ proposed that the anomalies observed in LBWC were caused by a primary defect/ectodermal deficiency of the embryonic disc. The affected area and severity may depend on the defect size and location in the ectoderm.

In general, none of the theories individually accounts for each and every anomaly observed in ABS, so it has been proposed that it is a multifactorial pathology with involvement of different processes. ${ }^{35}$

\section{Risk factors (Table 3)}

The increased risk for ABS among young parents has been attributed to the interaction of genetic factors and age-related environmental factors (greater exposure to tobacco, alcohol, and drugs). ${ }^{72}$ Tobacco has a vasoconstrictor effect ${ }^{94,95}$ and carbon monoxide has been associated with fetal hypoxia, the same that causes vascular disruption..$^{96,97}$ Cocaine is a potent vasoconstrictor and may damage the uteroplacental blood flow during the critical periods of development. 28,76

Cignini et al. ${ }^{9}$ suggested that even though aceptaminophen has been associated with a small increase in the risk for gastroschisis, $9,94,98$ the risk observed for ABS should consider the confounding effect of this drug in the case of fever because it has been associated with vascular disruption, neural tube defects, and oral clefts. ${ }^{99,100}$

In relation to the increased frequency of ABS in populations living at high altitude, hypoxia has been proposed as a mechanism, although the genetic variants typical of these populations cannot be ruled out. ${ }^{9}$

\section{Clinical description (Table 4) \\ Limb anomalies}

Amniotic bands may or may not be attached to the fetus abnormal portions and be associated with deep constriction rings. Some bands are not connected to the amnion but join two abnormal portions of the fetus; other bands stem from the fetus or the amnion and remain loose without 
a distal anchor point. ${ }^{102}$ Patterson ${ }^{102}$ classified limb congenital anomalies into agenesis and constriction rings, whereas Hennigan and $\mathrm{KuO}^{115}$ classified constriction bands of the lower limbs by dividing their location into 4 areas and graded their severity. Homer et al. ${ }^{116}$ classified constriction bands of the upper limbs based on Hennigan and Kuo's proposal. ${ }^{115}$

\section{Craniofacial defects}

Craniofacial clefts are usually asymmetric and do not follow the anatomy of facial clefts; they extend from the lip and/or palate towards

TABLE 3. Risk factors for amniotic bands sequence

Sociodemographic factors

- Maternal age $<20$ years ${ }^{15,21,26,71}$

- Paternal age $<29$ years ${ }^{72}$

- Low socioeconomic and education level27,71

- Black population ${ }^{73}$

- Unplanned or unintended pregnancy ${ }^{16,27}$

- Smoking (> 15 cigarettes / day) 27,70-74

- Exposure to cocaine $e^{75,76}$

- Alcohol abuse ${ }^{28}$

- High glycemic index in the $\operatorname{diet}^{77}$

- Living in an attitudinal zone $>2000$ meters above sea level ${ }^{29,78}$

Obstetric factors

- Nulliparity 15,21,26,71,73

- Multiparity ${ }^{27}$

- Attempted abortion ${ }^{16,27}$

- Uterine or abdominal trauma ${ }^{79}$

- Bicornate uterus ${ }^{76,77}$

- Uterine fibroids ${ }^{80,81}$

- Ectopic pregnancy in one of the Fallopian tubes ${ }^{80,81}$

- Hemorrhage during the first trimester of gestation ${ }^{29}$

- Intrauterine infection ${ }^{51}$

- Oligohydramnios ${ }^{82}$

- Intrauterine device removal ${ }^{55,58,80,83-85}$

- Chorionic villus sampling or amniocentesis ${ }^{55,58,80,83-85}$

- Cerclage 55,58,80,83-85 $^{-1}$

- Fetoscopic laser surgery for twin-to-twin transfusion syndrome $^{55,58,80,83-85}$

- Preterm birth ${ }^{27,86}$

- Low birth weight for gestational age $e^{27,86}$

Systemic factors

- Fever during the first trimester of gestation ${ }^{29}$

- Diabetes ${ }^{87}$

- Obesity ${ }^{87}$

- Ehlers-Danlos syndrome type IV (OMIM \#130050)

- Osteogenesis imperfecta (OMIM \#166200) ${ }^{3}$

- Epidermolysis bullosa (OMIM \#131750 and \#226600) ) $^{3,88-91}$

Drug-related factors

- Aspirin and/or acetaminophen ${ }^{21,71,73,92}$

- Misoprostol ${ }^{93}$ the skull and may or may not be connected to the brain malformation caused by the amniotic bands, although "normal" cleft lip and palate cases have also been reported. ${ }^{47,117}$ Tessier ${ }^{118,119}$ classified facial clefts focusing on the orbit and assigning a number to each cleft counterclockwise. David et al. ${ }^{120}$ broadened the description of craniofacial clefts described by Tessier ${ }^{118}$ supported by twoand three-dimensional reconstruction studies by high-resolution computed tomography.

\section{Body wall defects and other anomalies}

Anterior abdominal wall defects (excluding gastroschisis, omphalocele, and umbilical hernia) are uncommon, large, and complex injuries, ${ }^{12}$ although some bands do not affect the body wall. $^{121-125}$

\section{DIAGNOSIS}

A histopathological analysis may show the absence of the amniotic membrane on the fetal surface of the chorionic sac (including the placenta), the remaining amnion on the umbilical cord base, and cell detritus or amniotic lamellae embedded on the chorionic surface. ${ }^{126,127}$

Imaging studies help to establish the location, type, and extent of the anomaly. Magnetic resonance imaging tests study the depth of constrictions, the extent of lymphedema, and muscular integrity, and define vascular anatomy (which may be anomalous) to propose a surgical approach and prevent vascular damage during surgery. ${ }^{127,128}$

Cytogenetic and molecular tools, in addition to being useful to rule out chromosomal numerical or structural alterations (fluorescence in situ hybridization, FISH) and genomic imbalances (comparative genomic hybridization, $\mathrm{CGH}$ ) and to analyze the single-nucleotide polymorphism by chromosomal microarray, ${ }^{129}$ allow to identify common, rare or new variants in deoxyribonucleic acid (DNA) with a high risk for ABS. This is the case of exome sequencing; however, it has successfully identified mutations in predominantly Mendelian phenotypes with high penetration alleles, whereas ABS may be caused by a combination of DNA variants, so it is necessary to perform a family-wide analysis and assess functional pathways that may be involved in ABS development to select the variants that should be validated by Sanger sequencing and, therefore, replicate the sequencing method in the family or the control population. ${ }^{130}$ 


\section{ANTENATAL DIAGNOSIS}

A two-dimensional ultrasound allows to detect the LBWC in the second trimester of gestation; however, unlike a three-dimensional ultrasound, it has certain limitations to obtain orthogonal multi-planar images of the cavity and the surface, which help to see the defect and the adjacent structures. ${ }^{131-134}$ A prenatal ultrasound marker suggestive of ABS is the presence of amnion loose in the cavity, ${ }^{135-137}$ so a fetal structural assessment should be done to rule out other anomalies. $18,19,33,109,131,134,138$

If an ultrasound image is indicative of amniotic band sequence, a differential diagnosis of the following is required:

a) Succenturiate lobed placenta: a separate mass of chorionic villi connected to the main part of the placenta by blood vessels inside the membranes. Blood flow is observed in the Doppler ultrasound. ${ }^{139}$

b) Intrauterine adhesions: the amnion and chorion layers are doubled. A Doppler ultrasound shows vascularity with arterial pulse consistent with the maternal heart rate. ${ }^{140-142}$
- Adhesions: intrauterine scarring secondary to curettage or surgery.

- Amniotic sheet: adhesion not related to the uterine lateral walls and completely surrounded by the chorion and the amniotic sac (in the incomplete presentation, there is a free-floating oval edge or "sperm sign"). ${ }^{140,143}$

c) Uterine septum: remaining from the middle septum secondary to a Mullerian alteration. ${ }^{139}$ It is located in the uterine fundus, with a base that is broader than the free end and does not come in contact with the fetus; inside it is possible to identify the maternal vascular flow. ${ }^{140}$

When amniotic bands are associated with fetal anomalies, it is necessary to rule out teratogenesis (including Toxoplasma gondii infections, rubella, cytomegalovirus, herpes, and other intrauterine infections) as well as chromosomal alterations. ${ }^{131}$ The differential diagnosis should also consider monogenic diseases such as Adams-Oliver syndrome (OMIM \#100300, ARHGAP31 gene; OMIM \#616028, NOTCH1 gene; OMIM \#614219, DOCK 6 gene) ${ }^{3}$ and Roberts syndrome (OMIM \#268300, ESCO2 gene). ${ }^{3}$

TABLE 4. Anomalies identified in amniotic bands sequence

\begin{tabular}{|c|c|c|}
\hline \multirow[t]{4}{*}{$\operatorname{Limbs}^{6,8,22,33,101-105}$} & Deformation & Hip dislocation, talipes equinovarus, talipes valgus \\
\hline & Defects & Complete \\
\hline & & Partial (terminal, transversal, and intercalary) \\
\hline & Digital & $\begin{array}{l}\text { Syndactyly, pseudo-syndactyly, camptodactyly, polydactyly, } \\
\text { brachydactyly, nail hypoplasia, altered dermatoglyphics }\end{array}$ \\
\hline \multirow[t]{6}{*}{ Head and neck $\mathbf{k}^{9,22,28,29,33,106-114}$} & $\begin{array}{l}\text { Head and } \\
\text { central nervous } \\
\text { system }\end{array}$ & $\begin{array}{l}\text { Encephalocele, exencefalia, acephaly, anencephaly / acrania, } \\
\text { holoprosencephaly, microcephalus, ventriculomegaly and/or } \\
\text { hydrocephalus, septo-optic dysplasia, periventricular nodular } \\
\text { heterotopia, polymicrogyria, cortical dysplasia with pachygyria, } \\
\text { hypoplasia of the corpus callosum, craniosynostosis, myelocele, } \\
\text { meningocele, myelomeningocele }\end{array}$ \\
\hline & Face & Asymmetry, agnathia, clefts \\
\hline & Eyes & $\begin{array}{l}\text { Orbital hypertelorism, eyelid coloboma, anophthalmia/microphthalmia, } \\
\text { ectropion }\end{array}$ \\
\hline & Nose & Choanal atresia \\
\hline & Mouth & $\begin{array}{l}\text { Microstomia, high-arched palate, aglossia/microglossia, } \\
\text { cleft lip and / or palate }\end{array}$ \\
\hline & Ears & Low ear implantation or rotation, poorly-differentiated pinna, melotia \\
\hline \multirow[t]{7}{*}{ Other ${ }^{9}, 10,16,22,28,29,106$} & Cardiovascular & Heart anomalies \\
\hline & Respiratory & Lung anomalies \\
\hline & Skin & $\begin{array}{l}\text { Skin appendages, hamartomatous pedicles, pterygium, } \\
\text { sacrococcygeal appendage }\end{array}$ \\
\hline & Chest & Thoracoschisis, supernumerary nipples \\
\hline & $\begin{array}{l}\text { Abdominal and } \\
\text { gastrointestinal }\end{array}$ & $\begin{array}{l}\text { Abdominoschisis, tracheoesophageal fistula, diaphragmatic defect, } \\
\text { hepatomegaly, intestinal malrotation, single umbilical artery, } \\
\text { short or ectopic umbilical cord, imperforate anus }\end{array}$ \\
\hline & Genitourinary & Epispadias, bladder exstrophy, cloacal exstrophy \\
\hline & Skeletal & $\begin{array}{l}\text { Cervical ribs, segmentation defects of the vertebrae, } \\
\text { kyphoscoliosis, arthrogryposis }\end{array}$ \\
\hline
\end{tabular}




\section{Management}

ABS requires a multidisciplinary approach. An ultrasound control should be done to determine whether amniotic bands (if present) show spontaneous lysis, ${ }^{144,145}$ whether the process is causing fetal deformation or if it is necessary to release band constriction in utero by fetoscopy. ${ }^{146-150}$

Based on the post-natal classification suggested by Weinzweig, ${ }^{151}$ Hüsler et al. ${ }^{150}$ proposed the prenatal staging of ABS in the limbs by Doppler velocimetry and artery pulsatility index (Table 5). ${ }^{150}$ Fetuses that may benefit from amniotic band release by fetoscopy are those with an abnormal flow (compared to the opposite limb or available reference values) in the distal portion of the limb. ${ }^{150,152,153}$ The objective of this procedure is to prevent irreversible injuries and have a potentially reconstructible limb post-natally. ${ }^{153}$

If diagnosis is made post-natally, the classification proposed by Hennigan and $\mathrm{Kuo}^{115}$ is used to select the surgery, i.e., an elective and cosmetic surgery for patients with superficial bands that do not affect the lymphatic or circulatory drainage or an emerging treatment for patients with deep bands affecting the anatomical and functional integrity of the site involved. ${ }^{106}$ Craniofacial and body wall anomalies should be approached by surgery based on clinical practice guidelines individually for each case. ${ }^{154}$

\section{Prognosis}

Prognosis depends on the time of diagnosis (most cases are diagnosed post-natally), type and location of anomalies, and may vary from cosmetic to life-threatening consequences. ${ }^{21}$ The antenatal diagnosis of amniotic adhesions has been associated with an adverse prognosis. Most craniofacial and body wall defects are incompatible with extrauterine life. ${ }^{127}$ In relation to amniotic bands, the most important fetal prognostic factor is perfusion of the distal portion of the affected limb. ${ }^{150}$ There have been reports of fetal death caused by umbilical cord strangulation by an amniotic band, ${ }^{2,155,156}$ although spontaneous resolution of constriction bands has also been reported. ${ }^{145,150}$

In the case of post-natal diagnosis of anomalies in the limbs, prognosis is good following surgical repair.

\section{Genetic counseling}

To date, ABS is considered a sporadic, probably multifactorial event with a risk of recurrence similar to that of the general population $(<1 \%)$, although familial cases have been reported for which the risk should be estimated for each family in particular. ${ }^{6,28,40-44}$

\section{DISCUSSION}

The higher prevalence of ABS among fetuses $<20$ weeks of gestation and stillbirths implies that this disease has been under-diagnosed. Different risk factors and a great variability of clinical manifestations and prognoses have been reported. At present, ABS may be diagnosed antenatally, which means potential benefits, specifically in the presence of amniotic bands that could be released by fetoscopy to prevent irreversible injuries and have the possibility of reconstructing the affected limb.

\section{REFERENCES}

1. Higginbottom MC, Jones $\mathrm{KL}$, Hall $\mathrm{BH}$, et al. The amniotic band disruption complex: timing of amniotic rupture and variable spectra of consequent defects. I Pediatr 1979;94(4):544-9.

2. Kalousek DK, Bamforth S. Amnion rupture sequence in previable fetuses. Am J Med Genet 1988;31(1):63-73.

TABLE 5. Antenatal staging of amniotic bands sequence involving the limbs ${ }^{143,144}$

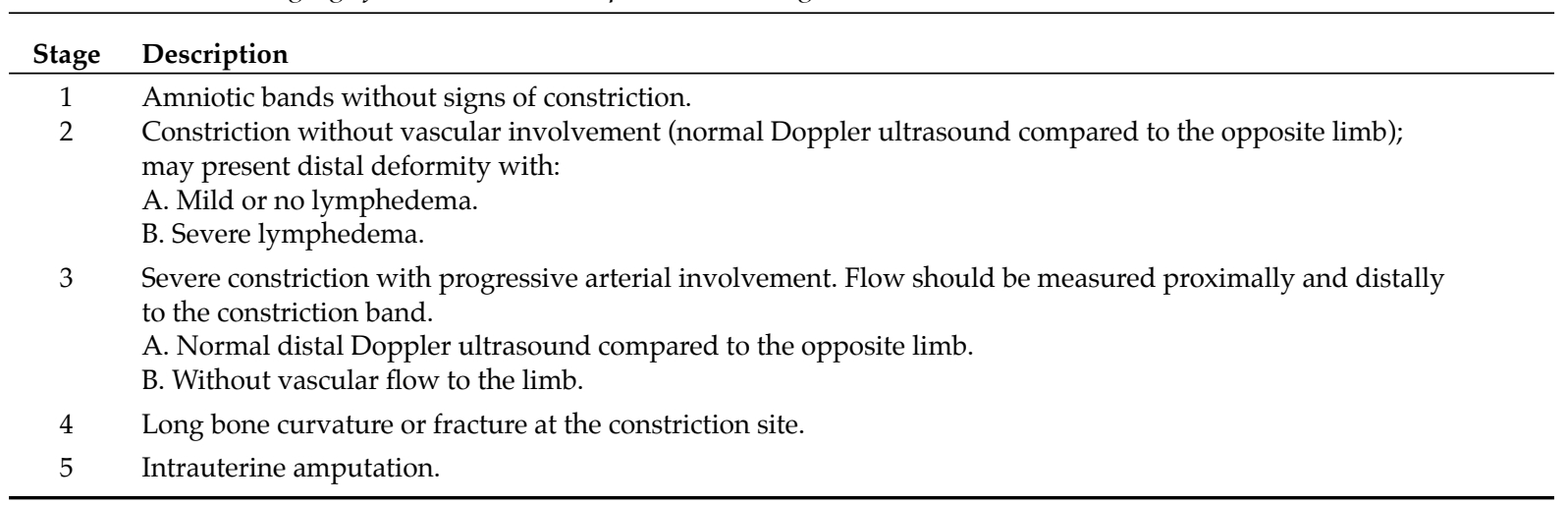

During stages 2-5, amniotic bands may or may be been seen by ultrasound. 
3. OMIM Online Mendelian Inheritance in Man. An online catalog of human genes and genetic disorders. [Accessed on: January 31st, 2017]. Available at: https: / / www.omim. org.

4. Hennekam RC, Biesecker LG, Allanson JE, et al. Elements of morphology: general terms for congenital anomalies. Am J Med Genet A 2013;161A(11):2726-33.

5. Seeds JW, Cefalo RC, Herbert WN. Amniotic band syndrome. Am J Obstet Gynecol 1982;144(3):243-8.

6. Levy R, Lacombe D, Rougier $Y$, et al. Limb body wall complex and amniotic band sequence in sibs. Am J Med Genet A 2007;143A(22):2682-7.

7. Torpin R. Amniochorionic mesoblastic fibrous strings and amniotic bands: associated constricting fetal malformations or fetal death. Am J Obstet Gynecol 1965;91:65-75.

8. Bodamer OA, Popek EJ, Bacino C. Atypical presentation of amniotic band sequence. Am J Med Genet 2001;100(2):100-2.

9. Cignini P, Giorlandino C, Padula F, et al. Epidemiology and risk factors of amniotic band syndrome, or ADAM sequence. J Prenat Med 2012;6(4):59-63.

10. Jamsheer A, Materna-Kiryluk A, Badura-Stronka M, et al. Comparative study of clinical characteristics of amniotic rupture sequence with and without body wall defect: further evidence for separation. Birth Defects Res A Clin Mol Teratol 2009;85(3):211-5.

11. Martínez-Frías ML. Epidemiological characteristics of amniotic band sequence (ABS) and body wall complex (BWC): are they two different entities? Am J Med Genet 1997;73(2):176-9.

12. Martínez-Frías ML. Clinical and epidemiological characteristics of infants with body wall complex with and without limb deficiency. Am J Med Genet 1997;73(2):170-5.

13. Kruszka P, Uwineza A, Mutesa L, et al. Limb body wall complex, amniotic band sequence, or new syndrome caused by mutation in IQ Motif containing K (IQCK)? Mol Genet and Genomic Med 2015;3(5):424-32.

14. Herrmann J, Opitz JM. Naming and nomenclature of syndromes. Birth Defects Orig Artic Ser 1974;10(7):69-86.

15. Garza A, Cordero JF, Mulinare J. Epidemiology of the early amnion rupture spectrum of defects. Am J Dis Child 1988;142(5):541-4.

16. Lowry RB, Bedard T, Sibbald B. The prevalence of amnion rupture sequence, limb body wall defects and body wall defects in Alberta 1980-2012 with a review of risk factors and familial cases. Am J Med Genet A 2017;173(2):299-308.

17. Pagon RA, Stephens TD, McGillivray BC, et al. Body wall defects with limb reduction anomalies: a report of fifteen cases. Birth Defects Orig Artic Ser 1979;15(5A):171-85.

18. Van Allen MI, Curry C, Gallagher L. Limb body wall complex: I Pathogenesis. Am J Med Genet 1987;28(3):52948.

19. Moerman P, Fryns JP, Vandenberghe K, et al. Constrictive amniotic bands, amniotic adhesions, and limb-body wall complex: discrete disruption sequences with pathogenic overlap. Am J Med Genet 1992;42(4):470-9.

20. Russo R, D’Armiento M, Angrisani P, et al. Limb body wall complex: a critical review and a nosological proposal. $A m$ J Med Genet 1993;47(6):893-900.

21. Guzmán-Huerta ME, Muro-Barragán SA, AcevedoGallegos S, et al. Amniotic band sequence: prenatal diagnosis, phenotype descriptions, and a proposal of a new classification based on morphologic findings. Rev Invest Clin 2013;65(4):300-6.

22. Opitz JM, Johnson DR, Gilbert-Barness EF. ADAM "sequence" part II: hypothesis and speculation. Am J Med Genet A 2015;167A(3):478-503.

23. EUROCAT European surveillance of congenital anomalies. [Accessed on: 30 de enero de 2017]. Available at: http: / / www.eurocat-network.eu.

24. Froster UG, Baird PA. Amniotic band sequence and limb defects: data from a population-based study. Am J Med Genet 1993;46(5):497-500.

25. Ossipoff V, Hall BD. Etiologic factors in the amniotic band syndrome: a study of 24 patients. Birth Defects Orig Artic Ser 1977;13(3D):117-32.

26. Bower C, Norwood F, Knowles S, et al. Amniotic band syndrome: a population-based study in two Australian states. Paediatr Perinat Epidemiol 1993;7(4):395-403.

27. CzeizelAE, Vitéz M, KodajI, et al.Study of isolated apparent amniogenic limb deficiency in Hungary, 1975-1984. Am J Med Genet 1993;46(4):372-8.

28. Luehr B, Lipsett J, Quinlivan JA. Limb-body wall complex: a case series. J Matern Fetal Neonatal Med 2002;12(2):132-7.

29. OrioliI M, Ribeiro MG, Castilla EE. Clinical and epidemiological studies of amniotic deformity, adhesion, and mutilation (ADAM) sequence in a South American (ECLAMC) population. Am JMed Genet A 2003;118A(2):13545.

30. Koskimies E, Syvänen J, Nietosvaara Y, et al. Congenital constriction band syndrome with limb defects. J Pediatr Orthop 2015;35(1):100-3.

31. Luebke HJ, Reiser CA, Pauli RM. Fetal disruptions: assessment of frequency, heterogeneity, and embryologic mechanisms in a population referred to a communitybased stillbirth assessment program. Am J Med Genet 1990;36(1):56-72.

32. Streeter GL. Focal deficiencies in fetal tissues and their relation to intra-uterine amputation. Washington: Carnegie Institution of Washington;1930.

33. Hunter AG, Seaver LH, Stevenson RE. Limb-body wall defect. Is there a defensible hypothesis and can it explain all the associated anomalies? Am J Med Genet A 2011;155A(9):2045-59.

34. McKenzie J. Amniotic bands. In: Balls M, Wild E, eds. The early development of mammals, the second symposium of the British Society for Developmental Biology. New York: Cambridge University Press; 1975.

35. Halder A. Amniotic band syndrome and/or limb body wall complex: split or lump. Appl Clin Genet 2010;3:7-15.

36. Smits-Van Prooije AE, Vermeij-Keers C, Poelmann RE, et al. The formation of mesoderm and mesectoderm in 5-to41 somite rat embryos cultured in vitro, using WGA-Au as a marker. Anat Embryol (Berl) 1988;177(3):245-56.

37. Hartwig NG, Vermeij-Keers C, De Vries HE, et al. Limb body wall malformation complex: an embryologic etiology? Hum Pathol 1989;20(11):1071-7.

38. Wei X, Sulik KK. Pathogenesis of craniofacial and body wall malformations induced by ochrotoxin A in mice. Am J Med Genet 1993;47(6):862-71.

39. Sadler TW. Langman's medical embriology. 12th ed. Philadelphia:Wolters Kluwer Health/Lippincott Williams \& Wilkins; 2012

40. Lubinsky M, Sujansky E, Sanger W, et al. Familial amniotic bands. Am J Med Genet 1983;14(1):81-7.

41. Gellis SS. Constrictive bands in the human. Birth Defects Orig Artic Ser 1977;13(1):259-68.

42. TemtamySA,McKusickVA.Digitalandothermalformations associated with congenital ring constrictions. Birth Defects Orig Artic Ser 1978;14:547.

43. Etches PC, Stewart AR, Ives EJ. Familial congenital amputations. J Pediatr 1982;101(3):448-9.

44. Lockwood C, Ghidini A, Romero R. Amniotic band syndrome in monozygotic twins: prenatal diagnosis and pathogenesis. Obstet Gynecol 1988;71(6 Pt 2):1012-6.

45. Bhat BV, Pandey KK, Srinivasan S, et al. Intrauterine amputation associated with amniotic band syndrome. 
Indian Pediatr 1991;28(2):188-91.

46. Jabor MA, Cronin ED. Bilateral cleft lip and palate and limb deformities: a presentation of amniotic band sequence?. J Craniofac Surg 2000;11(4):388-93.

47. Davies BR, Giménez-Scherer JA, Hernández-Sierra JF. Fetal amniotic adhesions. Their topographic concordance with regionally clustered malformations. Arch Med Res 2001;32(1):48-61.

48. Romero-Valdovinos M, Galván-MontañoA, Olivo-DíazA, et al. The amniotic band syndrome in the rat is associated with the activation of transforming growth factor-B. Am J Pathol 2015;185(8):2076-82.

49. Eckes B, Zigrino P, Kessler D, et al. Fibroblast-matrix interactions in wound healing and fibrosis. Matrix Biol 2000;19(4):325-32.

50. Yeh YC, Wei WC, Wang YK, et al. Transforming growth factor-beta 1 induces Smad3-dependent beta 1 integrin gene expression in epithelial-to-mesenchymal transition during chronic tubulointerstitial fibrosis. Am J Pathol 2010;177(4):1743-54.

51. Romero-Valdovinos M, Bobadilla-Sandoval N, Flisser A, et al. The epithelial mesenchymal transition process may contribute to the pathogenesis of amniotic band syndrome. Med Hypotheses 2014;83(3):306-11.

52. Herva R, Karkinen-Jääskeläinen M. Amniotic adhesion malformation syndrome: fetal and placental pathology. Teratology 1984;29(1):11-9.

53. Yang SS, Levine AJ, Sanborn JR, et al. Amniotic rupture, extra-amniotic pregnancy, and vernix granulomata. Am J Surg Pathol 1984;8(2):117-22.

54. Clavert JM, Clavert A, Berlizon A, et al. Abnormalities resulting from intra-adnexal injection of glucose in the rabbit embryo-an experimental model of "amniotic disease". Prog Pediatr Sur 1978;12:143-64.

55. Kino Y. Clinical and experimental studies of the congenital constriction band syndrome with emphasis on its etiology. J Bone Joint Sur Am 1975;57(5):636-43.

56. Kennedy LA, Persaud TV. Pathogenesis of developmental defects induced in the rat by amniotic sac puncture. Acta Anat (Basel) 1977;97(1):23-35.

57. Daya M, Makakole M. Congenital vascular anomalies in amniotic band syndrome of the limbs. J Pediatr Surg 2011;46(3):507-13.

58. Davies BR, Giménez-Scherer JA. Comparison of the amniotic band disruption complex with acardiac twins does not support its vascular origin. Fetal Pediatr Pathol 2007;26(2):87-99.

59. Hummel KP. The inheritance and expression of disorganization, an unusual mutation in the mouse. J Exp Zool 1958;137(3):389-423.

60. Robin NH,Abbadi N, McCandless SE, et al. Disorganization in mice and humans and its relation to sporadic birth defects. Am J Med Genet 1997;73(4):425-36.

61. Donnai D, Winter RM. Disorganisation: a model for 'early amnion rupture'? J Med Genet 1989;26(7):421-5.

62. Crosby JL, Varnum DS, Nadeau JH. Two-hit model for sporadic congenital anomalies in mice with the disorganization mutation. Am J Hum Genet 1993;52(5): 866-74.

63. Isidor B, Baujat G, Le Caignec C, et al. Congenital skin pedicles with or without amniotic band sequence: extending the human phenotype resembling mouse disorganization. Am J Med Genet A 2009;149A(8):1734-9.

64. Purandare SM, Ernst L, Medne L, et al. Developmental anomalies with features of disorganization (Ds) and amniotic band sequence (ABS): a report of four cases. $A m$ J Med Genet A 2009;149A(8):1740-8.
65. Lowry RB, Yong SL. Cleft lip and palate, sensorineural deafness, and sacral lipoma in two brothers: a possible example of the disorganisation mutant. J Med Genet 1991;28(2):135-7.

66. Nakamura K, Nanjyo B. Congenital skin tube pedicle associated with the constriction band syndrome. Plastic Reconstr Surg 1992;89(4):746-50.

67. Corona-Rivera JR, Corona-Rivera E, Navarro-RamírezP, et al. Lumbopedal skin pediclein an infant with amniotic band syndrome: a disorganization-like defect?. Clin Dysmorphol 2003;12(1):51-4.

68. Onal EE, Türkylmaz C, Atalay Y, et al. Tubular skin appendage, renal agenesis and popliteal web: a further example of the human homologue of disorganization (Ds). Clin Dysmorphol 2005;14(2):89-91.

69. Robin NH, Franklin J, Prucka S, et al. Clefting, amniotic bands, and polydactyly: a distinct phenotype that supports an intrinsic mechanism for amniotic band sequence. Am J Med Genet A 2005;137A(3):298-301.

70. Heyne TF, Robin NH, Lin AE. Sxiteenth-century German woodcut of a male infant with possible disorganization. Clin Genet 2016;89(2):269-71.

71. Werler MM, Louik C, Mitchell AA. Epidemiologic analysis of maternal factors and amniotic band defects. Birth Defects Res A Clin Mol Teratol 2003;67(1):68-72.

72. Grewal J, Carmichael SL, Yang W, et al. Paternal age and congenital malformations in offspring in California, 19892002. Matern Child Health J 2012;16(2):385-92.

73. Werler MM, Bosco JL, Shapira SK. Maternal vasoactive exposures, amniotic bands and terminal transverse limb defects. Birth Defects Res A Clin Mol Teratol 2009;85(1):52-7.

74. Hoyt AT, Canfield MA, Romitti PA, et al. Associations between maternal periconceptional exposure to secondhand tobacco smoke and major birth defects. Am J Obstet Gynecol 2016;215(5):613.e1-11.

75. Webster WS, Brown-Woodman PD. Cocaine as a cause of congenital malformations of vascular origin: experimental evidence in the rat. Teratology 1990;41(6):689-97.

76. Viscarello RR, Ferguson DD, Nores J, et al. Limb-body wall complex associated with cocaine abuse: further evidence of cocaine's teratogenicity. Obstet Gynecol 1992;80(3 Pt 2):523-6.

77. Yazdy MM, Mitchell AA, Liu S, et al. Maternal dietary glycaemic intake during pregnancy and the risk of birth defects. Paediatr Perinat Epidemiol 2011;25(4):340-6.

78. Castilla EE, Lopez-Camelo JS, Campaña H. Altitude as a risk factor for congenital anomalies. Am J Med Genet 1999;86(1):9-14.

79. Webster WS, Lipson AH, Brown-Woodman PD. Uterine trauma and limb defects. Teratology 1987;35(2):253-60.

80. Graham JM, Miller ME, Stephan MJ, et al. Limb reduction anomalies and early in utero limb compression. J Pediatr 1980;96(6):1052-6.

81. Matsunaga E, Shiota K. Ectopic pregnancy and myoma uteri: teratogenic effects and maternal characteristics. Teratology 1980;21(1):61-9.

82. Vázquez Rueda F, Ayala MontoroJ, Blanco López F, et al. Síndrome de bandas de constricción congénitas. Rev Cir Infantil 1999;9(3):163-7.

83. Yang SS. ADAM sequence and innocent amniotic band: manifestations of early amnion rupture. Am J Med Genet 1990;37(4):562-8.

84. Firth HV, Boyd PA, Chamberlain P, et al. Severe limb abnormalities after chorion villus sampling at 56-66 days' gestation. Lancet 1991;337(8744):762-3.

85. Winer N, Salomon LJ, Essaoui M, et al. Pseudoamniotic band syndrome: a rare complication of monochorionic twins with fetofetal transfusion syndrome treated by laser coagulation. Am J Obstet Gynecol 2008;198(4):393.e1-5. 
86. Gün I, Muhçu M, Müngen E, et al. Effect of an amniotic sheet on pregnancy outcomes. JUltrasound Med 2013;32(5): 807-13.

87. Durga R, Renukadevi TK. Amniotic band syndrome- a dreaded condition. J Clin Diagn Res 2016;10(1):QD04-5.

88. Young ID, Lindenbaum RH, Thompson EM, etal. Amniotic bands in connective tissue disorders. Arch Dis Child 1985;60(11):1061-3.

89. Marras A, Dessì C, Macciotta A. Epidermolysis bullosa and amniotic bands. Am J Med Genet 1984;19(4):815-7.

90. Katorza E, Weisz B, Sevillia J, et al. Unusual prenatal sonographic findings of epidermolysis bullosa mimicking an amniotic band constriction ring. J Ultrasound Med 2009;28(1):73-5.

91. Snadecki H, Criscione V, Jaquith A, et al. Dystrophic epidermolysis bullosa associated with amniotic band syndrome. Pediatr Dermatol 2014;31(2):212-6.

92. Hernandez RK, Werler MM, Romitti P, et al. Nonsteroidal antiinflammatory drug use among women and the risk of birth defects. Am J Obstet Gynecol 2012;206(3):228.e1-8.

93. González CH, Marques-Días MJ, Kim CA, et al. Congenital abnormalities in Brazilian children associated with misoprostol misuse in first trimester of pregnancy. Lancet 1998;351(9116):1624-7.

94. Torfs CP, Velie EM, Oechsli FW, et al. A population-based study of gastroschisis: demographic, pregnancy, and lifestyle risk factors. Teratology 1994;50(1):44-53.

95. Mitchell AA, Gilboa SM, Werler MM, et al. Medication use during pregnancy, with particular focus on prescription drugs: 1976-2008. Am J Obstet Gynecol 2011;205(1):51.e1-8.

96. Webster WS, Abela D. The effect of hipoxia in development. Birth Defects Res C Embryo Today 2007;81(3):215-28.

97. Werler MM. Teratogen update: pseudoephedrine. Birth Defects Res A Clin Mol Teratol 2006;76(6):445-52.

98. Torfs CP, Katz EA, Bateson TF, et al. Maternal medications and environmental exposures as risk factors for gastroschisis. Teratology 1996;54(2):84-92.

99. Nilsen NO. Vascular abnormalities due to hyperthermia in chick embryos. Teratology 1984;30(2):237-51.

100.Dreier JW, Andersen AM, Berg-Beckhoff G. Systematic review and meta-analyses: Fever in pregnancy and health impacts in the offspring. Pediatrics 2014;133(3):e674-88.

101.Taub PJ, Bradley JP, Setoguchi Y, et al. Typical facial clefting and constriction band anomalies: an unusual association in three unrelated patients. Am JMed Genet 2003;120A(2):25660 .

102.Patterson TJ. Congenital ring-constrictions. Br J Plast Surg 1961;14:1-31.

103.Ribeiro MG, Castilla EE, Orioli IM. Can amputated digits point to clues about etiology? Am J Med Genet A 2004;128A(1):93-4.

104.Gold NB, Westgate MN, Holmes LB. Anatomic and etiological classification of congenital limb deficiencies. Am J Med Genet A 2011;155A(6):1225-35.

105.Little KJ, Cornwall R. Congenital anomalies of thehand-principles of management. Orthop Clin North Am 2016;47(1):153-68.

106.Pagon RA, Stephan MJ. Septo-optic dysplasia with digital anomalies. J Pediatr 1984;105(6):966-8.

107.Wu YC, Yang ML, Yuan CC. Prenatal diagnosis of anophthalmos with limb-body wall complex. Prenat Diagn 2000;20(9):769-70.

108.Pilu G, Nicolaides K, Ximenes R, et al. Diagnosis of fetal abnormalities-the 18-23 weeks scan. London: ISUOG \& Fetal Medicine Foundation; 2002.

109. Yamanouchi H, Ota T, Imataka G, et al. Congenital bilateral perisylvian syndromeassociated with congenital constriction band syndrome. J Child Neurol 2002;17(6):448-50.
110.Harrison IM, Brosnahan D, Phelan E, et al. Septo-optic dysplasia with digital anomalies- a recurrent pattern syndrome. Am J Med Genet A 2004;131A(1):82-5.

111. Stevens CA, Dobyns WB. Septo-optic dysplasia and amniotic bands: further evidence for a vascular pathogenesis. Am J Med Genet A 2004;125A(1):12-6.

112.Das G, Gayen S, Bandyopadhyay S, et al. Ethmocephaly with amniotic band syndrome. Middle East Afr JOphthalmol 2012;19(4):429-31.

113.Sarnat HB, Flores-Sarnat L. Neuroembryology and brain malformations: an overview. Handb Clin Neurol 2013;111:117-28.

114.Jagtap SV, Saini N, Jagtap S, et al. Otocephaly: Agnathiamicrostomia-synotia syndrome- a rare congenital anomaly. J Clin Diagn Res 2015;9(9):ED03-4.

115. Hennigan S, Kuo KN. Resistant talipes equinovarus associated with congenital constriction band syndrome. J Pediatr Orthop 2000;20(2):240-5.

116. Homer LE, Mishra A, McArthur P. Amniotic constriction bands: a case series and proposed new classification system. Hand Surg 2015;20(1):121-6.

117. Rowlatt U. Cleft lip and palate associated with amniotic band limb amputations in a 20 week human fetus. Cleft Palate J 1979;16(2):206-9.

118. Tessier P. Anatomical classification of facial, cranio-facial and latero-facial clefts. J Maxillofac Surg 1976;4(2):69-92.

119. Winters R. Tessier clefts and hypertelorism. Facial Plast Surg Clin North Am 2016;24(4):545-58.

120.David DJ, Moore MH, Cooter RD. Tessier clefts revisited with a third dimension. Cleft Palate J 1989;26(3):163-84.

121.Craven CM, Carey JC, Ward K. Umbilical cord agenesis in limb body wall defect. AmJ Med Genet 1997;71(1):97-105.

122.Ben-Chaim J, Mathews RI, Gearhart JP. La extrofia de cloaca. Su anatomía, manejo y seguimiento. Rev Cir Infantil 1998;8:67-74.

123.Woo LL, Thomas JC, Brock JW. Cloacal exstrophy: a comprehensive review of an uncommon problem. J Pediatr Urol 2010:6(2);102-11.

124.Suzuki K, Matsumaru D, MatsushitaS, et al. Epispadias and the associated embryopathies: genetic and developmental basis. Clin Genet 2017;91(2):247-53.

125. ReinfeldtEngbergG, Mantel Ä, Fossum M, etal. Maternal and fetal risk factors for bladder exstrophy: a nationwideSwedish case-control study. J Pediatr Urol 2016;12(5): 304. e1-7.

126.Day-Salvatore DL, Guzman E, Weiberger B, et al. Genetics casebook. Amniotic band disruption sequence. J Perinatol 1995;15(1):74-7.

127.Chen H. Atlas of Genetic diagnosis and counseling. Heidelberg: Springer; 2012.

128.Laor T, Jaramillo D, Hoffer FA, et al. MR imaging in congenital lower limb deformities. Pediatr Radiol 1996;26(6):381-7.

129.De Wit MC, de Coo IF, Schot R, et al. Periventricular nodular heterotopia and distal limb deficiency: a recurrent association. Am J Med Genet A 2010;152A(4):954-9.

130. Krupp DR, Soldano KL, Garrett ME, et al. Missing genetic risk in neural tube defects: can exome sequencing yield an insight? Birth Defects Res A Clin Mol Teratol 2014;100(8):642-6.

131.Liu IF, Yu CH, Chang $\mathrm{CH}$, et al. Prenatal diagnosis of limb body-wall complex in early pregnancy using threedimensional ultrasound. Prenat Diagn 2003;23(6):513-4.

132.Chmait R, Pretorius D, Jones M, et al. Prenatal evaluation of facial clefts with two-dimensional and adjunctive threedimensional ultrasonography: a prospective trial. Am JObstet Gynecol 2002;187(4):946-9.

133.Rossi AC, Prefumo F. Correlation between fetal autopsy and prenatal diagnosis by ultrasound: a systematic review. Eur J Obstet Gynecol Reprod Biol 2016;210:201-6. 
134.Emanuel PG, Garcia GI, Angtuaco TL. Prenatal detection of anterior abdominal wall defects with US. Radiographics 1995;15(3):517-30.

135. López Ramón y Cajal C. Diagnóstico prenatal del síndrome de las bandas amnióticas. Prog Obstet Ginecol 2000;43: 354-63.

136.Zimmer EZ, Bronshtein M. Ultrasound observation of amnion dysmorphism at $14.5-16$ weeks. Prenat Diagn 1995;15(5):447-9.

137.Mahony BS, Filly RA, Callen PW, et al. The amniotic band syndrome: antenatal sonographic diagnosis and potential pitfalls. Am J Obstet Gynecol 1985;152(1):63-8.

138. Chen CP. Prenatal diagnosis of limb-body wall complex with craniofacial defects, amniotic bands, adhesions and upper limb deficiency. Prenat Diagn 2001;21(5):418-9.

139.Galeana Castillo C, Casas Patiño D, Rodríguez Torres A, et al. Síndrome de bandas amnióticas: correlación ecográfica y pieza anatómica. Arch Inv Mat Inf 2013;5(3):146-50.

140.Pons GA, Sáez AR, Sepúlveda LW. Brida amniótica, sinequia intrauterina y tabique mulleriano: Etiopatogenia, diagnóstico diferencial y pronóstico. Rev Chil Ultrason 2005;8(2):51-8.

141.Abuhamad AZ, Romero R, Shaffer WK, et al. The value of Doppler flow analysis in the prenatal diagnosis of amniotic sheets. J Ultrasund Med 1992;11(11):623-4.

142.Sherer DM, Lysikiewicz AJ. Doppler flow velocimetry assisted diagnosis of an intrauterine synechia during pregnancy. Am J Perinatol 2002;19(8):421-6.

143.Zaldivar Pascua Y. Caso interesante de lámina amniótica. Rev Med Hondur 2012;80(3):111-3.

144.Nishi T, Nakano R. Amniotic band syndrome: serial ultrasonographic observations in the first trimester. J Clin Ultrasound 1994;22(4):275-8.

145.Pedersen TK, Thomsen SG. Spontaneous resolution of amniotic bands. Ultrasound Obstet Gynecol 2001;18(6):673-4.

146.Quintero RA, Morales WJ, Phillips J, et al. In utero lysis of amniotic bands. Ultrasound Obstet Gynecol 1997;10(5): 316-20.

147.Keswani SG, Johnson MP, Adzick NS, et al. In utero limb salvage: fetoscopic release of amniotic bands for threatened limb amputation. J Pediatr Surg 2003;38(6):848-51.

148.Sentilhes L, VerspyckE, Eurin D, et al. Favourable outcome of a tight constriction band secondary to amniotic band syndrome. Prenat Diagn 2004;24(3):198-201.

149.Ronderos-DumitD, BriceñoF, Navarro H, et al. Endoscopic release of limb constriction rings in utero. Fetal Diagn Ther 2006;21(13):255-8

150.Hüsler MR, Wilson RD, Horii SC, et al. When is fetoscopic release of amniotic bands indicated? Review of outcome of cases treated in utero and selection criteria for fetal surgery. Prenat Diagn 2009;2(5)9:457-63.

151.Weinzweig N. Constriction band-induced vascular compromise of the foot: classification and management of the "intermediate" stage of constriction-ring syndrome. Plast Reconstr Surg 1995;96(4):972-7.

152.Wisser J, Kurmanavicius J, Müller C, et al. Pulsatility index in the fetal anterior tibial artery during the second half of normal pregnancy. Ultrasound Obstet Gynecol 1998;11(3):199203.

153.Soldado F, Aguirre M, Peiró JL, et al. Fetoscopic release of extremity amniotic bands with risk of amputation. J Pediatr Orthop 2009;29(3):290-3.

154.Muraskas JK, McDonnellJF, Chudik RJ, etal.Amniotic band syndrome with significant orofacial clefts and disruptions and distortions of craniofacial structures. J Pediatr Surg 2003;38(4):635-8.

155. Heifetz SA. Strangulation of the umbilical cord by amniotic bands: report of 6 cases and literature review. Pediatr Pathol 1984;2(3):285-304.

156.Armand R, Brenner DS, Sun CC. Pathologic quiz case: fetal death at 32 weeks of gestation. Arch Pathol Lab Med 2003;127(7):e317-8. 